Dorota Filipczak

University of Łódź

\title{
Transvestite M(other) in the Canadian North: Isobel Gunn by Audrey Thomas
}

\section{ABSTRACT}

The article focuses on the eponymous protagonist of Isobel Gunn, a Canadian feminist historical novel by Audrey Thomas, published in 1999. Based on a real story, the novel fictionalizes the life of an Orcadian woman who made her transit from the Orkney Islands to the Canadian north in male disguise, and was only identified as a woman when she went into labour. The article juxtaposes the novel against its poetic antecedent The Ballad of Isabel Gunn, published by Stephen Scobie in 1983. In the article Gunn's fate as a unique transvestite $\mathrm{m}$ (other) in the Canadian north is compared to the fate of famous transvestite saint Joan of Arc. Though removed from each another historically and geographically, both women are shown to have suffered similar consequences as a result of violating the biblical taboo on cross-dressing. Isobel's sudden change of status from a young male colonizer to the defenseless colonized is seen in the context of managing the female resources by colonial authorities. At the same time, the fact that Isobel allows herself to be deprived of her son is analyzed in the light of insights on the maternal by Julia Kristeva and Luce Irigaray. The absence of the mother and the ensuing condition of her offspring's orphanhood are shown as a consequence of reducing the position of the mother to that of an imperial servant, the fruit of whose body can be freely used and abused by the male imperial authority.

Keywords: Audrey Thomas, Isobel Gunn, Canada. 


\section{Facts and Fiction About Isabel/Isobel GunN}

Isobel Gunn (1999) by Audrey Thomas reconstructs the story of an Orcadian woman who challenged stereotypes in Prince Rupert's land from which white women were excluded on principle during the British colonization of Canada (Cox 138). William H. New states in A History of Canadian Literature that the novel is based on "a real-life event" previously depicted in a poem by Stephen Scobie (301). Described as a "feminist historical novel" (Kuester 318), the text by Thomas seeks to supplement the official version of events reported in the journal of Alexander Henry, the younger (Gough 418-19), an excerpt from which opens the narrative and frames it in a politically neutral tone.

The quoted passage recounts the amazement of the chief factor at "an extraordinary affair" which occurred in Pembinah on 29 December 1807 when "one of Mr. Heney’s Orkney lads" succumbed to severe pain which soon resulted in "dreadful lamentations." As it turned out the lad was "a pregnant girl, and actually in childbirth" (Thomas xix). The journal does not state what made the previous concealment of a girl possible in the all-male camp. Biographical Dictionary of Scottish Women provides rudimentary facts about Isabel Gunn, alias Fubister, a daughter of John Fubister whose paternal name she adopted when she entered employment with the Hudson Bay Company. Her son was officially registered in the colony as John Scarth's child. After the discovery of her actual sex Isabel was sent back to Scotland with her son where both lived in poverty (152). Stephen Scobie's work entitled The Ballad of Isabel Gunn was the first attempt to reinvent the real woman's story by referring to the official description of "the extraordinary affair." Known for his skilled use of dramatic monologue Scobie reconstructed Isabel's own voice and spun a yarn about the young woman's passionate attachment to a man, which made her follow him to Canada in male disguise until her sex was revealed as a result of childbirth. Scobie's ballad revolves around the motif of female devotion, self-sacrifice and spurned love. His Isabel is driven by the desire for togetherness, which ends the moment her lover abandons her for the indigenous woman he has cohabited with before, as was the pattern in the imperial colonies spawned by western fantasies of power translated into sexual terms.

Audrey Thomas provides the real woman with a radically different life story, which involves a traumatic past and a troubling future. Just like Scobie, Thomas crosses the gender line and fictionalizes Isobel's adventures from the perspective of the opposite sex. The main focalizer of the narrative is a Presbyterian parson, Magnus Inkster, a native of the Orkney Islands and unique listener to Isobel's story. Significantly, his name brings to mind an 
Orcadian saint murdered after Easter circa 1117 and credited with healing miracles (Antonsson 73-77). Instead of dwelling on the romantic loveaffair, Thomas chooses to show Gunn as a victim of a horrendous rape by the very man who was complicit with her plans and facilitated her transit to Canada to later claim what he considered his due in a particularly brutal way. Restrictions on white women in the colonies (Stoler 42) rendered Isobel defenseless in the hands of male colonizers the moment her sex was revealed. After giving birth to her son the heroine is returned to the only appropriate role for a woman and prevented from competing with men whom she was able to impress with her courage and resilience when in disguise. She is reduced to the position of a washerwoman. Her contact with the men who treated her as their companion is replaced by contact with their soiled clothes. Thus she becomes a recipient of literal dirt, as well the site of Kristevan abjection because she dared to question the boundary of the symbolic order. Besides, her place is now with native women who serve the colonizers in various ways. Thus she turns from a male colonizer into the female colonized.

As the novel unfolds, the reader does not know that the eponymous heroine's death was its catalyst. Left alone to die, Isobel is looked after by the widowed Magnus in her final hours and afterwards. He keeps vigil over her and decides to make the vigil last as long as custom has it. "It's a woman's task" (Thomas 21), Magnus says, but he is determined to sit through several days near Isobel's dead body, and his vigil becomes a pretext for the ethical task of memory. Magnus recreates Isobel in his private text by offering empathy and testimony. Thus the protagonist comes back to life, or is replaced by a narrative. The lives of Magnus and Isobel stand in startling contrast. He was the only son of loving parents; she was one of many daughters of a drunken father who staggered into the hut after childbirth, snatched the newborn, and parted her legs to see what sex the next offspring was. Infuriated at another failure, he threw the baby down and rushed out, leaving the mother mute with pain and grief. The emotional unavailability of Isobel's parents is offset by images from Magnus's childhood, his parents' mutual attraction, contentment with each other and joy with their child. Brought up in this household, Magnus manages to retain the gift for togetherness. As a mature man he marries a widow with three daughters and is quite happy to treat the young siblings as his own children. As such he represents a spectacular contrast to Isobel's callous and violent father.

The atmosphere of early family idyll in Magnus's household is suddenly disrupted by a chilling event. By accident, Magnus finds himself in the company of his father and the father's friend, the local doctor, when both are summoned on an adult errand; its goal is to subdue a madwoman, 
who turns out to be Isobel's mother. Having given birth to one more girl after Isobel, the woman throws the baby into the fire, and is soon taken to prison where she eventually commits suicide. Both Magnus and Isobel witness the moment when the distraught mother is led away for good. Magnus often observes that it must have been Isobel's early life that led her to be like a boy. It may well have been her father's rejection that imprinted itself on her later choices. The parson's emotional intelligence makes him reason like a precursor of psychoanalysis. He explains Isobel's masculine manner by the weight of her early traumas. Isobel defies female meekness and passivity. She grows up to be as strong as a man; she ploughs the field, and steals eggs from the nests suspended on dangerously vertiginous cliffs. She derides maternal duties and says no to future marriage.

Isobel and Magnus exchange stereotypical gender attributes. He is a meek "man of the cloth" (Thomas 122), sensitive after his mother, gentle after his father. Isobel is tough, strong and determined. Like her mother and father she hates everything that is connected with women's fate. Unlike Magnus she does not pine for company; she never feels isolated when on her own; she is driven by a single goal, to achieve her transit to the new world in the new male identity that she appropriates from a boy who drowned. Accordingly, she chooses to name herself John Fubbister. In the male disguise she makes it to Hudson Bay, partly due to the only man who recognized her as his friend's sister. As long as she is protected by her male identity she lives a happy life, until she is raped by the very man who knew her as a woman, which soon leads to her undoing. The rapist cum protector dies a sudden death as a result of an accident. His actual role is never revealed to anybody except parson Inkster. The woman's former friends treat her baby as the fruit of a secret love, thinking she risked everything to follow her beloved man. "Let them say what they likeIsobel tells Magnus-I know the truth of bid" (Thomas 59). The fictional confession undermines Scobie's romanticizing vision of passion and abandonment. Thus Thomas's narrative becomes a counter-commentary to the androcentric assumption that the only reason for Isobel leaving home in male disguise was the desire to follow her man and not her choice to live a better life for her own sake.

\section{Transvestite Mother and Transvestite Saint}

Magnus, who arrived in Prince Rupert's land after Isobel's return from her transvestite condition to her previous identity, empathizes with her and is moved by her love for the little boy whose smile brightens the routine of the colonial settlement, even if his mother is ostracized for what she did, 
or to be more accurate, for what she did not do. Whatever was accepted and tolerated in Isobel when she was a man now becomes a major fault. The unmarried chief factor who covets Isobel's bright child because he has no heir, and desires no mixed progeny by an Amerindian, thus sums up her situation:

She is barely above a savage herself-an illiterate peasant who ran around barefoot most of the year and when she became a woman showed her contempt for society and God's law by disguising herself as a man and following her lover to the bay. (Thomas 123)

It is on the grounds of her apparent moral degeneration that $\mathrm{Mr}$ Morton considers Isobel unfit to bring up her child, and skillfully brings about the separation of mother and son, whom he wishes to adopt. The very comparison to a savage echoes Stoler's explanation of the word "degeneration" as the loss of one's racial identity (61-62). Identified with a savage, Isobel becomes the territory that was subject to rape, and now is subject to pillage. Her only resource-her son-is claimed by the chief factor. Translating this into the ideas of Luce Irigaray, the "father" forbids the child bodily contact with the mother (Anderson 114). Physically and metaphorically the mother is erased from colonial discourse, while the fruit of her body ends up appropriated by the man in a position of authority.

Morton's words about Isobel's "contempt for society and God's law" immediately bring to mind another woman in disguise, Joan of Arc, an illiterate peasant and "holy transvestite" who decided to save France from the English during the One Hundred Years War (Broome Saunders 83). Joan was vilified by the English and abandoned by the French. When she decided to give up her male clothes upon the urging of the church authorities, she was bound to face degradation. She no longer belonged with the privileged male sex. Her victory was appropriated by the weak French king and his followers the moment they began to feel stronger.

In this respect, Thomas's novel seems to be a distant reflection of the situation because Isobel's child who is the first racially pure child in the colony is appropriated by the chief factor who finds the boy useful for his plan. The mother is sent back to Scotland where she eventually dies in penury. The boy's origin is suppressed because the chief factor who intends to raise him blackmails and bullies everybody into silence, thus depriving the boy of his mother not only physically but also spiritually.

In France it was only the rehabilitation of Joan of Arc that led to recognizing her contribution to the French victory and which allocated to Joan her rightful place in historical discourse. Her enemies called Joan of Arc "a courtesan" or "the Armagnac whore" because she stayed in the all- 
male company in the military camp (Edmunds 50). After being captured by, or rather conveniently abandoned to, the English, she was exposed to the constant voyeurism of the guards keeping watch in her cell. Also, she was continually threatened with punitive sexual violence, and began to wear male clothes again in an attempt to protect herself against such invasions (Warner 130). As a warrior maid she violated the famous and literally accepted taboo from the Book of Deuteronomy (22:5) connected with a ban on crossdressing; thus she was tried for violating the divine law. Some reports have it that the proceedings connected with her trial lasted so long because she was pregnant as a result of a prison rape. Even if this has not been substantiated by historical sources, her fate offers a strikingly familiar antecedent to the vicissitudes of Isobel Gunn who was bound to face retribution for crossing over to the territory of the opposite sex.

Labelled "a loose woman" and "a camp-follower in disguise," Isobel did not protest her innocence (Thomas 136). It would have been useless. When Magnus Inkster proposes marriage to her out of friendship and concern for her child, she refuses the offer. As a rape victim she has dissociated herself from her own body and rejects any intimate contact with men. Her child, however, senses Inkster's fond approval and spontaneously calls him father. When this happens for the first time, Magnus is suddenly overwhelmed by an emotion he has never felt before and realizes what he has missed out on in his solitary life. This momentary experience of fatherhood paves the way for his later decision to get married and adopt his wife's children by another man, the way he wanted to adopt James. James's actual foster father, Mr Morton, grows suspicious because he realizes the boy's indifference and refusal to call him father despite constant requests. Just as he brought about Isobel's departure, Morton arranges for Magnus Inkster to leave Prince Rupert's land as "persona non grata." On the day of the parson's departure James calls him father once again, but now this takes place in public and becomes a major insult to the actual foster father who has gone to great lengths to erase the mother and father of choice from the adopted boy's history. Magnus Inkster's role in the story is his healing influence on Isobel and his work on her testimony, which he dutifully preserves and remembers due to the education he acquired. Like Joan of Arc's story, Isobel's confession is saved from oblivion due to the mediation of an empathetic male listener. His education and vocation provide the reader with the necessary distance to Isobel's story, which he pieces together from the pained confessions of an uneducated woman. In Scobie's version Isabel is far less simplistic and capable of critical judgement on a passage from Mr Henry's journal about which she says: 
Alexander Henry was no better, have you seen / what he wrote? that nonsense / (just like a man) about "round, white breasts" / as if I would bother with that, my / water broken, my belly contracting, men / haven't the guts to write the truth / of what a woman suffers ... (Scobie 50)

Thomas's simple, though defiant, Orcadian strikes the reader as much more credible, also due to her Orcadian speech which makes her stand out in Magnus's smooth narrative.

\section{Colonial Orphanhood in the Canadian Context}

In the conclusion to the novel voiced by a contemporary narrator, Thomas shows the gap in the family history of Isobel's son. Several generations later an anonymous mother tells her son that his great-grandfather was not sure whether the man who had brought him up was really his father. The mother's absence from the story is completely bypassed, lost in the telling by another woman who does not even wonder about this omission. Is this Thomas's implicit comment on how women contributed to their own absence from the family or public discourse? Isobel allows herself to be persuaded that she will be an impediment to her son's career, because they will both be reduced to penury on her return home. Thus she exchanges her maternal support for the dubious prospects of her son becoming a gentleman. This proves that despite her immense courage Isobel was prone to manipulation, the simple reason being her belief in the worthlessness of female life or maternal support. The mother herself agreed to the contract. Perhaps it could not have been otherwise. Her own mother had abandoned her children in a way that was much more destructive, literally and emotionally. In the light of Thomas's novel one can venture another comment; the mother's place is in her absence from the official discourse, and in the erasure of her contribution. This connects with the comments of Luce Irigaray who discusses the forgotten debt to the maternal under patriarchy (Boulous Walker 15). The issue remains particularly pertinent in the process of appropriating female reproductive resources by imperial authorities.

Incidentally, Thomas achieves a skillful rewriting of Dickens's Great Expectations where we never get to know Pip's parents. Both his mother and father are names on a gravestone, and the protagonist is transformed into a gentleman on the strength of a convict's money that is laundered as a result. Magnus Inkster called Prince Rupert's land a northern equivalent of Van Diemen's land for a reason (Thomas 95). Like Australia in Pip's case, it becomes the subconscious of the disoriented Canadian family whose distant 
descendant asks a question about his origin. It is far from a coincidence that it is this boy out of the five boys in the family, who, for no reason at all, conceives a dream of becoming a sailor. He leaves his household like his ancestress Isobel and goes to Europe where he joins the British navy. Like Isobel he changes his name, and therefore the news of his death in the Second World War never reaches his family. He loses his life when his warship is torpedoed in Scapa Flow of all places, that is to say, in the space that was like the inner sea for Orkney people such as Magnus and Isobel.

The physical and spiritual efforts of Isobel and Magnus respectively went into the making of the colony and the status of its chief factor. Having appropriated the fruit of Isobel's body and of Magnus's mindMagnus gave the boy his first lessons-Mr Morton abandons his adopted boy eventually. The chief factor returns to England like Magwitch but dies an heirless man, leaving his legacy to no descendant. The hope that had sustained Isobel in the moments of isolation and anguish is never fulfilled. Her son is not only cut off from any information about her, but he never returns to the British Isles physically as a result. It is only his descendant who asks a question about his origin that unwittingly ends up closest to the answer, but he dies at sea.

Thomas's engagement with the theme can be grasped through Kristeva's concept of primeval and inchoate semiotic suppressed by the patriarchal symbolic (Kristeva 13, Smith 15). The fluid, maternal semiotic associated with the abject and abjected mother throws light on Isobel's status in the colony and on her later marginalization. Her son will always be intrigued by women whose faces are scarred by smallpox and will yearn to touch their cheeks, much to their astonishment and fright. But this is his buried memory of contact with the mother whose face was disfigured by smallpox, which eliminated her from the group of marriageable or marketable girls at an early age. Isobel confessed to Magnus that James touched her as if to heal her; a distant echo of that gesture from the time of perfect togetherness with the mother remained with him forever. Isobel's twentieth-century descendant is also eliminated from the discourse of private family memory. Curious about his personal history he merges back into it in the waters of Scapa Flow, as if he rejoined the amniotic fluid of the primeval unity with the body of the lost mother whose name gives the novel its title.

\section{Reclaiming the North in Canadian Literature by Women}

Thomas joins the women writers who seek to reclaim the Canadian north discursively. Let me mention only two of them; Jane Urquhart and Aritha van Herk. In Urquhart's novel The Underpainter the reader comes to appreciate 
the marginalized Sarah, a woman used and abused by her lover, the famous painter whose fascination with the north is translated into emotional frigidity in the relationship with the one who loves and inspires him. Interestingly, the chief factor from Thomas's novel is also an artist; his portraits of people and drawings of beavers amaze Inkster who wonders how it is possible to connect artistic talent and total emotional obtuseness. As for Aritha van Herk, her novel The Tent Peg, in which a woman modelled on biblical Jael stakes her territory in an all-male camp, forms another parallel to Thomas's text. Van Herk uses a biblical ancestress who drove the tent peg into the temple of the enemy thus depriving him of life and winning the case for the Israelites. Van Herk's JL drives her tent peg into the male discourse on the north, disrupting it but also allowing for the mining of hidden emotional resources. Thomas uncovers the woman who existed as a historical character and voices her so as to emphasize the Canadian debt to the suppressed maternal. Joan of Arc's story allows for the exposure of the experiences of other underprivileged women of low origin: women who may not have achieved a comparable military feat, but who nonetheless contributed to historical discourse in ways that are overlooked on similarly sexist grounds.

\section{Works Cited}

Anderson, Pamela Sue. A Feminist Philosophy of Religion. Oxford: Blackwell, 1998. Print.

Antonsson, Haki. St. Magnús of Orkney: A Scandinavian Martyr-Cult in Context. Leiden: Brill, 2007. Print.

Biographical Dictionary of Scottish Women. Ed. Elizabeth L. Ewan, Sue Innes, Sian Reynolds and Rose Pipes. Edinburgh: Edinburgh UP, 2007. Print.

Boulous Walker, Michelle. Philosophy and the Maternal Body: Reading Silence. London: Routledge 2002. Print.

Broome Saunders, Clare. Women Writers and Nineteenth-Century Medievalism. Berlin: Springer, 2009. Print.

Cox, Bruce. Native People, Native Lands: Canadian Indians, Inuit and Metis. Montreal: McGill-Queen's, 1987. Print.

Edmunds, Joan. The Mission of Joan of Arc. Forest Row: Temple Lodge, 2008. Print.

Gough, Barry. "Henry Alexander." Dictionary of Canadian Biography. Vol. 5. Ed. George W. Brown and Francess G. Halpenny. Toronto: U of Toronto P, 1983. 418-19. Print.

Kristeva, Julia. Powers of Horror: An Essay on Abjection. Trans. Leon S. Roudiez. New York: Columbia UP, 1982. Print. 
Kuester, Martin. "The English-Canadian Novel from Modernism to Postmodernism." History of Literature in Canada: English-Canadian and French-Canadian. Ed. Reingard M. Nischik. Rochester: Camden, 2008. 310-29. Print.

New, William H. A History of Canadian Literature. Montreal: McGillQueen's, 2003. Print.

Scobie, Stephen. The Ballad of Isabel Gunn. Kingston: Quarry, 1987. Print. Smith, Anne-Marie. Julia Kristeva: Speaking the Unspeakable. London: Pluto, 1998. Print.

Stoler, Laura Ann. Carnal Knowledge and Imperial Power: Race and the Intimate in Colonial Rule. Berkeley: U of California P, 2002. Print.

Thomas, Audrey. Isobel Gunn. Toronto: Penguin, 2000. Print.

Warner, Marina. Joan of Arc. The Image of Female Heroism. Oxford: Oxford UP, 2013. Print.

Dorota FilipczaK teaches literatures in English and translation theory in the Institute of English Studies, University of Łódź. Her monograph on Malcolm Lowry was published in The Malcolm Lowry Review (Wilfrid Laurier University, Ontario, 199899). Her publications include Unheroic Heroines: The Portrayal of Women in the Writings of Margaret Laurence (Łódź UP, 2007), "Is Literature Any Help in Liberating Eve and Mary?" in New Topics in Feminist Philosophy of Religion, ed. Pamela Sue Anderson (Springer, 2010), "Gender and Space in 'The Albanian Virgin'” in Alice Munro: Understanding, Adapting and Teaching, ed. Mirosława Buchholtz (Springer, 2016), and Brian Moore's Eponymous Heroines: Representations of Women and Authorial Boundaries (Peter Lang, 2018). She has published seven books of poetry, and is a member of the Association of Polish Writers.

dorota.filipczak@uni.lodz.pl 